\title{
ARTICLES
}

\section{EFFICACY OF LIFE SKILLS EDUCATION ON MANAGEMENT OF CRITICAL THINKING SKILLS AMONG ADOLESCENCE GIRLS IN SELECTED SCHOOL AT KANYA KUMARI DISTRICT, TAMIL NADU, INDIA}

Mrs. Merlin Nesa Kumari* I Dr. Sukhda Sharma**

${ }^{*}$ Research Scholar, Himalayan University, Itanagar, Arunachal Pradesh, India.

**Research Supervisor, Himalayan University, Itanagar in Arunachal Pradesh, India. DOI: http://doi.org/10.47211/idcij.2021.v08i04.005

\section{ABSTRACT}

Background: Adolescent years mark the transition from childhood to adulthood. This phase, of almost a decade, is very critical for the physical, intellectual and emotional growth in the life of any individual. This period entails a lot of learning, unlearning and relearning for a successful future life. While adolescent are forming new social bonds, comprehending new viewpoints, and are willing to emulate and relate new learning to real-life challenges, they deal better when equipped with education on skill-set required to meet the challenges of day today life. Life skills competencies are enablers that include psychosocial competencies and interpersonal skills which assist people make knowledgeable selections, analyse the situations critically and creatively, talk effectively, construct lifelong cherished relationships, learn empathy, and lead their lives in a healthy and meaningful manner.

Objective of the study: The objectives of the study were to assess the efficacy of critical thinking skills among adolescent girls and to find the association between critical thinking skills and selected demographic variables (age, religion, siblings, education status and occupation of the father and mother) of the adolescent girls.

Materials and Methods: Experimental pretest-posttest control group time series design was adopted for the study. The samples of the study were 418 girls between 13 to 17 years studying in $8^{\text {th }}$ to $11^{\text {th }}$ standards of selected schools.

Result: According to the statistical report life skill education improves critical thinking skills in the experimental group. Significant association between number of siblings and critical thinking skills was also observed.

Keywords: Critical thinking, Adolescent, Life skill education

\section{ABOUT AUTHORS:}

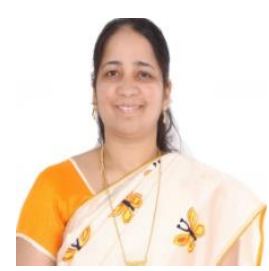

Author Mrs. Merlin Nesa Kumari is a Research Scholar at Himalayan University, Itanagar in Arunachal Pradesh, India.

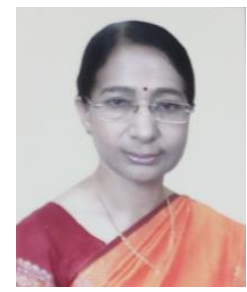

Author Dr. Sukhda Sharma is a Research guide at Himalayan University in Itanagar, Arunachal Pradesh, India. She has presented papers in various national and international conferences. 


\section{ARTICLES}

\section{INTRODUCTION}

Adolescents years are the years of most rapid and profound changes in an individual's physical and mental growth. The adolescent brain develops at a rate unseen since early childhood - making girls and boys hypersensitive to influences in their environments. Adolescents are keen to make sense of their environment, know the logic behind the way adults act and react, and comprehend new viewpoints. They wish to understand the priorities of their peers and are wish to behave and react accordingly when faced with similar real-life circumstances. Thus, they are able to discern and distinguish and so, can be molded in the desired direction by appropriate education (Kris Crabtree-Groff Briar, 2014). A critical feature exists in the timing of adolescent and a boom spurt among both genders. The girls' adolescent increase spurt at a median of about 10 years and grows at about approximately 12 years, those ages range, being lowest in evolved and the highest inside the poorest international locations. Their timing and the velocity of change vary according to different parameters (WHO, 2017). It is imperative for adolescents to develop critical thinking skills to navigate their life. Critical thinking is the capability to explore data and similarities in an objective way. Critical thinking can help the adolescent to identify and evaluate the attributes that influence attitudes and behavior, such as, morals, norms, values, peer pressure and the media (WHO, 2017). According to Sharma, N (2014) critical thinking is a faculty to inspect information and experiences in an unbiased manner. According to Ravindra et al. (2017) life skills training augment critical thinking capabilities, which promote positive influences on living life meaningfully, being accountable in the job and in forthcoming preparation for life journey too. Their study demonstrated the helpfulness of life skills training in increasing mental and physical health, pro-social behavior and lessening in behavioral problems, social problems \& self-destructive behaviors. The study brings to the fore major effect of LSE on interpersonal association and decline in violent behavior and behavioral problems. Throughout their study, life skills education should be incorporated in the syllabus of the adolescents. The effects of this education recommended the strange proficiency of teens to positive advancement and flexibility. Research showed that life skills education enhanced their psychosocial competencies. Study also showed that life skills education was effective in preventing a wide range of problems such as substance abuse, teenage pregnancies, violence, bullying etc. To promote self-confidence and self-esteem among the adolescents, research revealed that life skills training has a positive consequence and expands social development, emotional and social regulation, signifying an upsurge in compatibility of children and public health. Thus a need to impart life skill education was realized. Life skills education like critical thinking, problem solving, creative thinking, , decision making, stress management, coping with emotions, and effective communication skills facilitates the adolescents to be discerning of their emotions, appreciative of others viewpoint, be more interactive and forthcoming with their opinion.

\section{OBJECTIVES OF THE STUDY}

The objectives of the study were to were to assess the critical thinking skills among adolescent girls, to find out the association between critical thinking skills and selected demographic variables (age, religion, siblings, education status and occupation of the father and mother) of the adolescent girls, and to find correlation between life skill education and critical thinking skills. Researchers assumed that individual dissimilarities persist in response to critical thinking skills, critical thinking skills is cardinal to effective learning and that some adolescents possess naturally good critical thinking skills.

\section{METHODOLOGY}

The study involved experimental Pretest posttest control group time series design. The study was conducted in selected school of Kanyakumari district. The target population of this study was adolescent girls in the age group 13-17 years studying in the schools of Kanyakumari district.

Using random sampling technique 418 adolescent girl students' in the age group of 13 to 17 years were selected.

Permission from principal of the school and the informed consent from students were formally obtained. Back ground variables were collected from the students. Rating scale on critical thinking skills was used to collect the data.

\section{RESULTS AND OBSERVATION}

Data was analyzed by descriptive and inferential statistics. Descriptive statistics (frequency, percentage, mean and standard deviation) and inferential statistics chi square was used to assess the association between critical thinking skills and demographic variables. The findings are arranged in the following sections:

1) Distribution of demographic variables 


\section{ARTICLES}

2) Distribution of critical thinking skills

3) Association of critical thinking skills and selected demographic variables.

4) Correlation between critical thinking skills

1. Distribution of Demographic variables

Table 1: Frequency Distribution of Age Group in years, educational status of the mother \& father \& occupational status of the father \& mother

$\mathrm{N}=\mathbf{4 1 8}$

\begin{tabular}{|c|c|c|c|c|c|}
\hline \multirow[t]{2}{*}{ S. No } & \multirow{2}{*}{$\begin{array}{l}\text { Demographic } \\
\text { variables }\end{array}$} & \multicolumn{2}{|c|}{ Control group } & \multicolumn{2}{|c|}{ Experimental group } \\
\hline & & Frequency & Percentage & Frequency & Percentage \\
\hline & \multicolumn{5}{|l|}{ Age Group in years } \\
\hline & $14-15$ & 148 & $70.8 \%$ & 125 & $59.8 \%$ \\
\hline & $15-16$ & 45 & $21.5 \%$ & 47 & $22.5 \%$ \\
\hline & Above 16 & 16 & $7.7 \%$ & 37 & $17.7 \%$ \\
\hline & \multicolumn{5}{|l|}{ Number of siblings } \\
\hline & 1 & 25 & $12.0 \%$ & 16 & $12.0 \%$ \\
\hline & 2 & 89 & $42.6 \%$ & 25 & $12.0 \%$ \\
\hline & $3 \&$ above & 86 & $41.1 \%$ & 152 & $72.7 \%$ \\
\hline & \multicolumn{5}{|c|}{ Educational Status of the mother } \\
\hline & Illiterate & 17 & $8.1 \%$ & 3 & $1.4 \%$ \\
\hline & Primary & 41 & $19.6 \%$ & 20 & $9.6 \%$ \\
\hline & High School & 51 & $24.4 \%$ & 19 & $9.1 \%$ \\
\hline & $\begin{array}{l}\text { Higher } \\
\text { Secondary }\end{array}$ & 63 & $30.1 \%$ & 48 & $23.0 \%$ \\
\hline & Graduate & 25 & $12.0 \%$ & 95 & $45.5 \%$ \\
\hline & Post Graduate & 11 & $5.3 \%$ & 21 & $10.0 \%$ \\
\hline & Doctorate & 1 & $0.5 \%$ & 3 & $1.4 \%$ \\
\hline & \multicolumn{5}{|c|}{ Educational Status of the father } \\
\hline & Illiterate & 14 & $6.7 \%$ & 6 & $2.9 \%$ \\
\hline & Primary & 40 & $19.1 \%$ & 19 & $9.1 \%$ \\
\hline & High School & 41 & $19.6 \%$ & 34 & $16.3 \%$ \\
\hline & $\begin{array}{l}\text { Higher } \\
\text { Secondary }\end{array}$ & 60 & $28.7 \%$ & 43 & $20.6 \%$ \\
\hline & Graduate & 31 & $14.8 \%$ & 87 & $41.6 \%$ \\
\hline & Post Graduate & 21 & $10.0 \%$ & 19 & $9.1 \%$ \\
\hline & Doctorate & 2 & $1.0 \%$ & 1 & $0.5 \%$ \\
\hline & \multicolumn{5}{|c|}{ Occupational status of the mother } \\
\hline & $\begin{array}{l}\text { Private sector } \\
\text { employee }\end{array}$ & 31 & 14.8 & 104 & 49.8 \\
\hline & $\begin{array}{l}\text { Govt. sector } \\
\text { employee }\end{array}$ & 24 & $11.5 \%$ & 33 & $15.8 \%$ \\
\hline & Self-employed & 59 & $28.2 \%$ & 35 & $16.7 \%$ \\
\hline & Unemployed & 79 & $37.8 \%$ & 31 & $14,8 \%$ \\
\hline
\end{tabular}




\section{ARTICLES}

\begin{tabular}{lllll}
\hline Daily wages & 16 & $13.3 \%$ & 6 & $2.9 \%$ \\
$\begin{array}{l}\text { Occupational status of the father } \\
\begin{array}{l}\text { Private sector } \\
\text { employee }\end{array}\end{array}$ & $21.5 \%$ & 73 & $28.2 \%$ \\
$\begin{array}{l}\text { Govt. sector } \\
\text { employee }\end{array}$ & 36 & $17.2 \%$ & 30 & $15.8 \%$ \\
$\begin{array}{l}\text { Self-employed } \\
\text { Unemployed }\end{array}$ & 64 & $30.6 \%$ & 70 & $32.1 \%$ \\
Daily wages & 17 & $8.1 \%$ & 14 & $7.4 \%$ \\
\hline
\end{tabular}

Table: 2 Distribution of Critical thinking Skills among adolescent girls ( $N=418)$

\begin{tabular}{lllll}
\hline $\begin{array}{l}\text { Level of Critical thinking } \\
\text { Skills }\end{array}$ & Control Group & & Experimental Group \\
& $\mathbf{N}$ & $\mathbf{\%}$ & $\mathbf{N}$ & \% \\
\hline Good & 0 & $0.0 \%$ & 209 & $100.0 \%$ \\
Average & 56 & $26.8 \%$ & 0 & $0.0 \%$ \\
Poor & 153 & $73.2 \%$ & 0 & $0.0 \%$ \\
\hline
\end{tabular}

Repeated Measures ANOVA Critical thinking among adolescent girls between experimental and control group over a period of time

Table:3 Comparison of experimental group and control group on Critical thinking at different time points

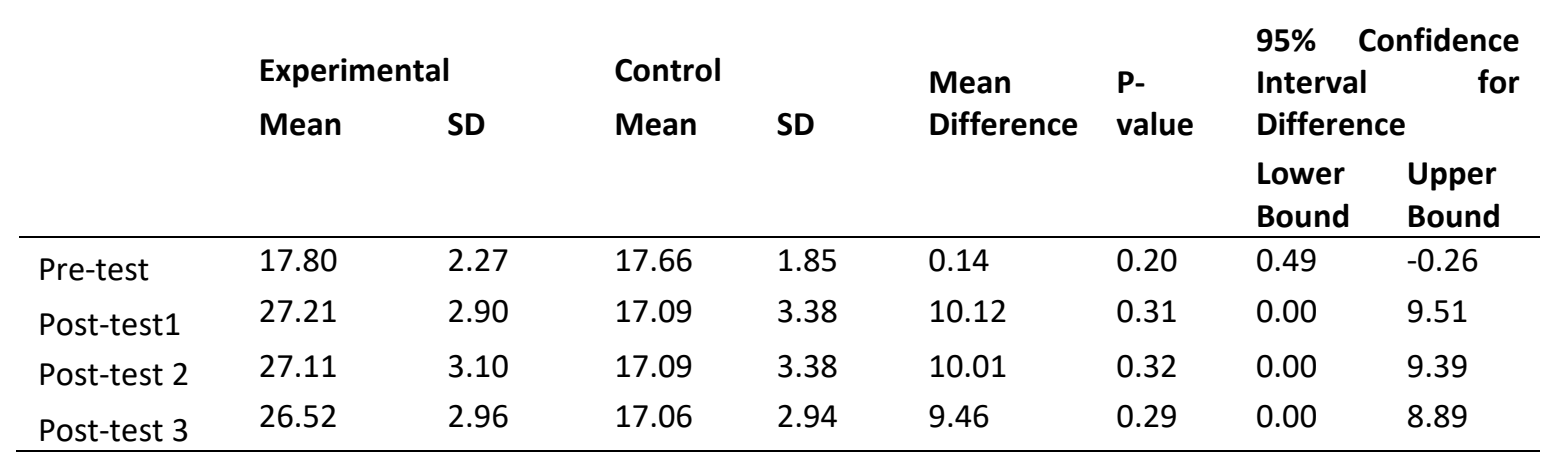

Association between Critical Thinking skills and selected demographic variables 


\section{ARTICLES}

Table: 4 Association between number of siblings and Critical Thinking skills

\begin{tabular}{|c|c|c|c|c|c|c|}
\hline & & Critical Thinking & & Total - n (\%) & & \\
\hline & & Average - $\mathrm{n}(\%)$ & Good - n (\%) & & $\begin{array}{l}\text { Chi } \\
\text { square }\end{array}$ & P-value \\
\hline Number & No siblings & 39 (9.4\%) & $2(100 \%)$ & 41 (9.8\%) & 8.755 & 0.013 \\
\hline & 1 & 114 (27.4\%) & $0(0.0) \%)$ & 114 (27.3\%) & & \\
\hline Siblings & 2 & 238 (57.2\%) & $0(0.0 \%)$ & 238 (56.9\%) & & \\
\hline & 3 and above & 25 (6.01\%) & $2(100 \%)$ & 25 (6.0\%) & & \\
\hline Age & $14-15$ & 27 (65.1\%) & $2(100 \%)$ & 273 (65.3\%) & 0.659 & 0.999 \\
\hline Group in & $15-16$ & 92 (22.1\%) & $0(0.0 \%)$ & 92 (22.0\%) & & \\
\hline & $>16$ & $53(12.7 \%)$ & $0(0.0 \%)$ & $53(12.7 \%)$ & & \\
\hline Mother & Illiterate & $20(4.8 \%)$ & $0(0.0 \%)$ & $20(4.8 \%)$ & 9.144 & 0.085 \\
\hline Educatio & Primary & $59(14.2 \%)$ & 2 (100\%) & $61(14.6 \%)$ & & \\
\hline $\mathrm{n}$ & High School & $70(16.8 \%)$ & $0(0.0 \%)$ & 70 (16.7\%) & & \\
\hline & $\mathrm{HSc}$ & $111(26.7 \%)$ & $0(0.0 \%)$ & $111(26.6 \%)$ & & \\
\hline & UG & $120(28.8 \%)$ & $0(0.0 \%)$ & $120(28.7 \%)$ & & \\
\hline & PG & 32 (7.7\%) & $0(0.0 \%)$ & 32 (7.7\%) & & \\
\hline & Doctorate & $4(1.0 \%)$ & $0(0.0 \%)$ & $4(1.0 \%)$ & & \\
\hline Father & Illiterate & 20 (4.8\%) & $0(0.0 \%)$ & $20(4.8 \%)$ & 9.639 & 0.085 \\
\hline Educatio & Primary & 57 (13.7\%) & $2(100 \%)$ & 59 (14.1\%) & & \\
\hline $\mathrm{n}$ & High School & 75 (18.0\%) & $0(0.0 \%)$ & 75 (17.9\%) & & \\
\hline & $\mathrm{HSC}$ & $103(24.8 \%)$ & $0(0.0 \%)$ & $103(24.6 \%)$ & & \\
\hline & UG & $118(28.4 \%)$ & $0(0.0 \%)$ & $118(28.2 \%)$ & & \\
\hline & PG & $40(9.6 \%)$ & $0(0.0 \%)$ & $40(9.6 \%)$ & & \\
\hline & Doctorate & $3(0.7 \%)$ & $0(0.0 \%)$ & $3(0.7 \%)$ & & \\
\hline Mother & Private sector & 135 (32.5\%) & $0(0.0 \%)$ & 135 (32.3\%) & 5.627 & 0.301 \\
\hline $\begin{array}{l}\text { Occupati } \\
\text { on }\end{array}$ & $\begin{array}{l}\text { Govt. sector } \\
\text { employee }\end{array}$ & $57(13.7 \%)$ & $0(0.0 \%)$ & 57 (13.6\%) & & \\
\hline & $\begin{array}{l}\text { Self- } \\
\text { employed }\end{array}$ & $94(22.6 \%)$ & $0(0.0 \%)$ & 94 (22.5\%) & & \\
\hline & Unemployed & $108(26.0 \%)$ & $0(0.0 \%)$ & $110(26.3 \%)$ & & \\
\hline & Daily wages & $22(55.3 \%)$ & $2(100 \%)$ & $22(5.3 \%)$ & & \\
\hline Father & Private sector & 135 (32.5\%) & $0(0.0 \%)$ & $118(28.2 \%)$ & 5.776 & 0.105 \\
\hline $\begin{array}{l}\text { Occupati } \\
\text { on }\end{array}$ & $\begin{array}{l}\text { Govt. sector } \\
\text { employee }\end{array}$ & $57(13.7 \%)$ & $0(0.0 \%)$ & 66 (15.8\%) & & \\
\hline & $\begin{array}{l}\text { Self- } \\
\text { employed }\end{array}$ & $94(22.6 \%)$ & $0(0.0 \%)$ & 134 (30.1\%) & & \\
\hline & Unemployed & 110 (26.3\%) & $0(0.0 \%)$ & 31 (7.4\%) & & \\
\hline & Daily wages & 22 (55.3\%) & $0(0.0 \%)$ & 69 (16.5\%) & & \\
\hline
\end{tabular}

From table 3 it is seen that there is no statistical significance difference between the Experimental and control group at the baseline Post-test1, Post-test2 and Post-test 3. Since p-value $>0.05$, there is no association between number of siblings; age group;education of mother and father; occupation of mother and father with critical thinking skills whereas there is an association of critical thinking skills with number of siblings. 


\section{ARTICLES}

\section{DISCUSSION}

There is significant statistical difference between the experimental and control group at the baseline Post-test1, Post-test2 and Post-test 3.The repeated measures Tests of Between-Subject ANOVA table shows that over time, there was a significant difference in critical thinking between the groups $p<0.0001$ specially with experimental group with post-test intervals.There is no association between age group, education of motherand father, occupation of mother and father whereas there is an association between number of siblings and Critical thinking skills.

\section{CONCLUSION}

The result indicated that all students were having poor critical thinking skills in control group whereas after giving life skills education on critical thinking skills to experimental group the level of critical thinking skills increased to good level. Critical thinking skills empowers the adolescent to advance very good interpersonal connections and to have healthier social support. It is a highly required and personally treasuredfeature to possess. Through life skills training and scientific guidance, we can advance the critical thinking skills of adolescents and thus we can lead them towards a very successful future life.

\section{REFERENCES}

1. Sharma N et al., (2013). CBSE http://cbseacademic.nic.in/" Teachers manual life skills for class VIII, I edition, CBSE publishers.

2. Prajapati R et. al.., (2017). Significance of Life Skills Education, Contemporary Issues in Education Research - First Quarter 2017 Volume 10, Number 1.

3. Tammi, R A et al., (2017). Neural correlates of empathic accuracy in adolescence among 155 participants', vol.12, no.11, pp.1701 -1710.

4. UNICEF (2017) https://apps.who.int/iris/bitstream/handle/10665/258504/WHO-FWC-NMC-17.3eng.pdf.

5. UNICEF (2020) technical note on life skills programsfor empowering adolescent girls: notes for practitioners on what works.

6. WHO (2017) Global Strategy for Women's, Children's and Adolescents' Health (2016-2030).

7. WHO (2017) Global Accelerated Action for the health of Adolescents: Guidance to support country implementation? Published report.

8. WHO (2017) https://www.who.int/life-course/partners/global-strategy/global-strategy-key-statistics03-11-2017.pdf?

9. WHO (2020) Life skills education school handbook Prevention of non-communicable diseases, Editing and design by Inis Communication - www.iniscommunication.com.

10. Zahra SharbafOlyaie (2016). The Effectiveness of Life Skills Training on Social Adjustment and Mental Disorders in Foster Kids and Adolescents, International Journal of Advanced Biotechnology and Research (IJBR) ISSN 0976-2612, Online ISSN 2278-599X, Vol-7, Special Issue-Number4-July, 2016, pp634-638 http://www.bipublication.co 